\title{
PEMIKIRAN MUHAMMAD ABDUH TENTANG POLITIK HUKUM, TAUHID, SOSIAL, DAN PENDIDIKAN
}

\author{
Umar Faruq Thohir*
}

\begin{abstract}
Modernization in the field of education is the most important part of social, economic, politic law, and aqeedah. That is, to build a modern society order, education is a very important aspect as a medium for the transformation of cultural values and knowledge. As stated by Belling and Toten that education is an instrument in modernization that is easier than modernization in the form of capital to buy technology. Education will encourage the development of intelligence and cultural products of society. The opinion of Belling and Toten clearly implies that investment in human resources through education will be more promising than in the form of capital to buy technology.
\end{abstract}

Keywords: social, economic, politic law, and aqeedab

\section{PENDAHULUAN}

Modernisasi dalam bidang pendidikan adalah bagian terpenting dari modernisasi sosial, ekonomi, politik, apalagi aqidah. ${ }^{1}$ Artinya, untuk membangun suatu tatanan masyarakat yang modern, pendidikan merupakan bagian terpenting sebagai media transformasi nilai budaya maupun pengetahuan. Sebagaimana dikemukakan oleh Belling dan

* Dosen Fak. Syariah Institut IlmuKeislaman Zainul hasan Genggong Kraksaan

${ }^{1}$ Abdul Munir Mulkhan, Paradigma Intelektual Muslim, Pengantar Filsafat Pendidikan dan Dakwah (Yogyakarta: SI Press, 1993), hlm. 123. 
Toten bahwa pendidikan merupakan instrumen dalam modernisasi yang lebih mudah dibandingkan dengan modernisasi dalam bentuk modal untuk membeli teknologi. Pendidikan akan mendorong berkembangnya intelegensi dan produk kebudayaan masyarakat. ${ }^{2}$ Pendapat Belling dan Toten tersebut jelas mengandung implikasi bahwa investasi sumber daya manusia lewat pendidikan akan lebih menjanjikan dari pada dalam bentuk modal untuk membeli teknologi.

Pada dasarnya mempersiapkan manusia lewat pendidikan sama halnya dengan transfer teknologi. Asumsi adanya relevansi yang signifikan antara pembaharuan dengan pendidikan adalah sebagaimana dikemukakan oleh Syafi'i Ma'arif, bahwa salah satu fungsi pendidikan adalah membebaskan masyarakat dari belenggu keterbelakangan. Itu artinya untuk mengadakan perubahan (pembaharuan) dalam masyarakat, yang menjadi kuncinya adalah pendidikan. ${ }^{3}$

Oleh karena itu pilihan Muhammad Abduh untuk secara tegas mengembangkan gerakan pembaharuan Islam melalui gerakan intelektual memiliki signifikansi yang kuat untuk terus dikaji. Persoalan yang berkaitan dengan sikap intelektualitas itu bukan hanya persoalan kelembagaan pendidikan, akan tetapi juga sikap mental yang dipengaruhi oleh budaya dan tata nilai dari sebuah masyarakat. Dari sini jelas bahwa masalah pendidikan mempunyai peran yang signifikan dalam menumbuhkan kembali intelektualitas umat Islam lewat jalur pendidikan. Konsepsi dasar pembaharuan (modernisasi) adalah mengubah tatanan lembaga pendidikan tradisional menjadi lembaga pendidikan modern. ${ }^{4}$

Berangkat dari perhatiannya terhadap pendidikan, dengan melihat keadaan masyarakat sekitar yang menurutnya menganut budaya keagamaan yang salah, Muhammad Abduh menawarkan pemikiran baru yang berbeda dengan kebanyakan penduduk mesir pada saat itu. Muhammad Abduh mengkritisi mayoritas penduduk yang cenderung pasrah karena dipengaruhi Teologi Jabariyah dan mengajaknya untuk

2 Belling dan Totten, Modernisasi dan Masalab Model Pembangunan (Jakarta: Yayasan Ilmu-ilmu Sosial, 1985), hlm. 19.

3 Syafi'i Ma'arif, Peta Intelektual Muslim Indonesia (Bandung: Mizan, 1994), hlm. 40; Abdul Munir Mulkhan, Paradigma Intelektual Muslim, hlm. 123; Belling dan Totten, Modernisasi dan Masalab Model Pembangunan, hlm. 19.

4 A. Mukti Ali, Alam Pikiran Islam Modern di Timur Tengah (Jakarta: Djambatan, 1995), hlm. 365. 
berparadigma Ikbtiyâr. ${ }^{5}$

Apapun itu, Muhammad Abduh (1849-1905) adalah tokoh yang monumental dan paling bersemangat melakukan pembaruan bagi dunia Islam. Muhammad Abduh sebagai tokoh pembaharuan dalam Islam patut dikenang dan diteladani, karena ia telah banyak berjuang untuk merubah kebiasaan masyarakat yang sebelumnya bersikap statis menjadi dinamis. ${ }^{6}$

Namun demikian, siapa sebenarnya Muhammad Abduh ini? Siapakah gurunya? Bagaimana sepak terjangnya? Apa saja pokok-pokok pemikirannya yang mengantarkannya pada pada laqab sang pembaharu? Persoalan-persoalan itulah yang akan dibahas dalam penelitian ini.

\section{PEMBAHASAN}

\section{A. Biografi Singkat dan Social Setting}

Muhammad Abduh termasuk keluarga petani sedang, yang memiliki 40 feddan (bahu). ${ }^{7}$ Ayahnya bernama Abduh Khairullah, penduduk kampung Nasr, daerah Subrakhit, Bukhairah. ${ }^{8}$ Karena tindasan penguasa negerinya, ayahnya meninggalkan kampung halamannya, untuk menuju propinsi Gharbiah, dan di sana ia menikah dengan Junainah, ${ }^{9}$ seorang wanita terpandang di kalangan keluarganya. Dari Junainah tersebut lahirlah seorang anak laki-laki pada tahun 1849 yang diberi nama Muhammad Abduh. ${ }^{10}$

5 A. Hanafi, Pengantar Theology Islam (Jakarta: al-Husna Zikra, 1995), hlm. 166-167.

6 Toto Suharto, Filsafat Pendidikan Islam, cetakan ke-I (Yogyakarta: al-Ruzz, 2006) hlm. 250

7 A. Hanafi, Pengantar Theology Islam, hlm.156.

8 Muhammad Rasyid Ridla, Tarikh al-Ustadz al-Imam al-Syaikh Muhammad 'Abduh, jilid III (Mesir: Dar al Manar, 1931), hlm. 13.

9 Ada literatur lain yang menyebutkan bahwa sebenarnya nama Ibu Muhammad Abduh bukanlah Junainah, melainkan Yatimah, yaitu seorang Turki, puteri dari Utsman al-Kabir yang memiliki silsilah sampai pada Umar bin alKhattab. Lihat Imam Munawir, Mengenal Pribadi 30 Pendekar dan Pemikir Islam dari Masa ke Masa (Surabaya: Bina Ilmu, 1985), hlm. 495; A. Hanafi, Pengantar Theology Islam, hlm. 156.

${ }^{10}$ Dalam literatur lain ada juga yang menyebut kelahirannya pada tahun 1848 . Namun setelah melakukan penelusuran, penyusun berkesimpulan bahwa Abduh dilahirkan pada tahun 1849. lihat Muhammad Rasyid Ridha, Tarikh al-Ustadz al- 
Setelah tinggal 15 tahun di Gharbiah, Abduh Khairullah dengan keluarganya pulang ke kampung halamannya yang semula, dimana ia kemudian menikah dengan seorang wanita lain, dan dari istri inipun lahir beberapa anak.

Setelah selesai menghafal selama dua tahun, pada tahun $1862 \mathrm{M}$. Muhammad Abduh dikirim ke kota Tanta untuk belajar ilmu-ilmu keislaman, tetapi pembelajarannya tidak berlangsung lama. ${ }^{11}$ Karena anjuran pamannya, Muhammad Abduh kembali ke Tanta pada tahun 1865 M, dan pada tahun berikutnya Muhammad Abduh pergi ke Kairo untuk belajar di al-Azhar.

Pada tahun $1872 \mathrm{M}$, Muhammad Abduh berhubungan dengan Jamaluddin al-Afghani dan menjadi muridnya yang setia. Karena pengaruh gurunya tersebut Muhammad Abduh terjun ke dunia persuratkabaran pada tahun 1876. Setelah menamatkan pendidikan di al-Azhar, ia diangkat menjadi guru di Dar al-Ulûm. Akan tetapi karena sebabsebab yang tidak diketahuinya, Muhammad Abduh dibebaskan dari jabatannya dan dikirim ke kampung halamannya, sedang Jamaluddin diusir dari Mesir.

Pada tahun 1880 M. Muhammad Abduh dipanggil oleh Kabinet Partai Liberal (Abrar) untuk diserahi jabatan kepala redaksi surat kabar al-Waqầ' al-Mishriyyah. ${ }^{12}$

Meskipun tujuan jamaluddin al-Afghani dan Muhammad Abduh sama, yaitu pembaharuan masyarakat Islam, namun cara untuk mencapai tujuan itu berbeda. Jamaluddin al-Afghani menghendaki jalan revolusi,

Imam al-Syaikh Muhammad 'Abduh, I:20; A. Hanafi, Pengantar Theology Islam, hlm. 156-157.

${ }^{11}$ Muhammad Abduh merasa jenuh dan kecewa karena metode yang digunakan hanyalah menghafal saja tanpa memberikan pemahaman yang lebih. Bahkan hingga dia belajar di al-Azhar pun (1866) juga merasakan kekecewaan terhadap metode pembelajaran yang demikian. Akhirnya, pada saat dewasa, dia memberikan masukan terhadap kampus agar merubah sistem hafalan dengan diskusi dan juga memasukkan beberapa pelajaran umum. Lihat Ahmad Amin, Zu'ama' al Islab fi alAshr al-Hadits (Kairo: Maktabah al-Nahdhah al-Misriyah, 1979), hlm. 58; Harun Nasution, Pembaharuan dalam Islam Sejarab Pemikiran dan Gerakan (Jakarta: Bulan Bintang, 1975), hlm. 60-61.

${ }^{12}$ Jamal Muhammad Ahmed, The Intellectual Origius of Egyptian Nasionalism (London: Oxford Universitas Press, 1960), hlm. 19-20; A. Hanafi, Pengantar Theology Islam, hlm.157. 
dan Muhammad Abduh memandang bahwa revolusi dalam lapangan politik tidak ada artinya, sebelum ada perubahan mental secara berangsurangsur.

Pemberontakan Urabi Pasya ${ }^{13}$ di Mesir telah mengakhiri kegiatan Muhammad Abduh, karena pada akhir tahun 1882 Muhammad Abduh diusir dari mesir. Muhammad Abduh pergi ke Beirut, kemudian pada awal tahun 1884 pergi ke Perancis dan di sana ia bertemu lagi dengan Jamaluddin al-Afghani. Kedua tokoh ini akhirnya mendirikan himpunan yang kuat dan menerbitkan majalah dengan nama yang sama.

Tujuan perhimpunan ini adalah membersihkan Mesir dari dominasi tentara asing dan mengingatkan bangsa-bangsa Timur akan bahaya Inggris. Meskipun majalah ini hanya berusia Delapan bulan saja, namun pengaruhnya sangat besar dalam membangun semangat kebangkitan Islam di Timur.

Atas nama perhimpunan tersebut, pada tahun 1884, Muhammad Abduh pergi ke London, dengan maksud untuk mengetahui niat yang sebenarnya dari orang-orang yang bertanggung-jawab di London, tentang pendudukan tentara Inggris di Mesir. Di sana ia disambut teman akrabnya, seorang Inggris bernama Blunt.

Dalam percakapannya dengan beberapa anggota parlemen Inggris dan dengan Lord Hartington, menteri peperangan Inggris, Muhammad Abduh dianggap sebagai tokoh revolusi Mesir dan Muhammad Abduh menyatakan dengan tegas keinginan rakyat Mesir akan kepergian tentara Inggris dari Mesir. Keinginan tersebut juga dikemukakan Muhammad Abduh kepada wakil-wakil surat kabar di Inggris, seperti Times, Truth, dan Pall Mall Gazette. ${ }^{14}$

Setelah berkunjung ke London, Muhammad Abduh kembali lagi ke Paris, kemudian pergi ke Tunis. Di sini ia mempropagandakan

${ }^{13}$ Pemberontakan Urabi Pasya dilancarkan oleh para perwira tinggi Mesir, mereka menuntut agar negeri Mesir dapat dipimpin kembali oleh Mesir sendiri. Namun pada akhirnya gerakan ditumbangkan oleh pemerintah dengan bantuan Inggris. Urabi Pasha waktu itu menjabat sebagai Ketua Partai Nasional (Hidzb alwathan). Sejak protes itu dilancarkan maka lahirlah semboyan terkenal. "Mishr Li al-Mishrinyyin" (Egypt for Egyptians). Lihat Mahmudul Haq, Muhammad Abduh: A Study of A Modern Thinker of Egypt (Aligarkh: Muslim University, 1970), hlm. 18-20.

${ }^{14}$ Usman Amin, Muhammad Abdub (ttp.: tp., tt.), hlm. 95. 
perhimpunannya itu, tetapi dengan tiba-tiba ia mengakhiri kegiatannya itu untuk pergi ke Beirut pada awal tahun $1885 \mathrm{M}$. dan menetap di sana.

Di Beirut, kegiatannya dialihkan pada bidang pendidikan, dan ia mulai mengajar serta mendalami ilmu-ilmu keislaman. Diantara hasilnya adalah kitab al-Radd alâ al-Dabriyyîn yang merupakan terjemahan dari buku Jamaluddin al-Afghani yang berbahasa Persia, buku Syarh al-Balâghah pada tahun 1885 dan Syarh Maqâmât Bad̂̀' al-Zamân alHamazanî pada tahun 1889 M.

Ketika sudah diperbolehkan kembali ke Mesir pada tahun 1889 M. Muhammad Abduh terus pergi ke Kairo. Muhammad Abduh kemudian segera diangkat menjadi Hakim pada Pengadilan Negeri di kota Banha (ibu kota provonsi Qalyubiah), kemudia pindah ke Pengadilan Negeri Zaqaziq (ibu kota provinsi Syarqiyah), kemudian pindah lagi ke Pengadilan Negeri Abidin (dalam kota Kairo). Karena pengalamannya yang banyak, dua tahun kemudian, Muhammad Abduh diangkat menjadi hakim tinggi pada Pengadilan Tinggi. ${ }^{15}$

pada tahun $1899 \mathrm{M}$, Muhammad Abduh memangku jabatan keagamaan tertinggi di Mesir, yaitu Muftî yang dijabatnya sampai ia wafat pada tahun 1905 M. Pada tahun 1899 M. ia juga menjadi anggota Dewan Perundang-undangan Parlemen yang merupakan fase permulaan kehidupan perlementer di Mesir. Pada tahun 1894 M. Muhammad Abduh menjadi pimpinan tertinggi al-Azhar yang dibentuk berdasarkan anjurannya. Di al-Azhar ini, selain mengadakan pembaharuanpembaharuan, ia juga aktif mengajar. ${ }^{16}$

\section{B. Pokok-Pokok Pemikiran Muhammad Abduh}

\section{Tauhid}

Dua hal yang dibicarakan dalam segi ini, yaitu:

\section{a. Aqidah Jabariah}

Muhammad Abduh memandang bahwa pengabdian diri secara mutlak terhadap mazhab-mazhab dan kitab-kitab yang sekarang pada masa-masa

${ }^{15}$ Abd. Halim Mahmud, Manâhij al-Muhassirîn (Mesir: Dar al-Kitab al-Mishri, tt.), hlm. 309.

${ }^{16}$ Ahmad Amin, Zu'ama' al Islah fi al-Ashr al-Hadits, hlm. 87-88. 
akhir Islam tidak saja berhubungan dengan lemah kepribadian-keilmuan pada masanya dan tidak sejalan dengan kepribadian Islam yang pertama dalam langkah-langkahnya yang positif dan baik terhadap Qur'an dan Sunnah, tetapi juga berhubungan dengan aqidah/paham Jabariah. ${ }^{17}$

Paham jabariyah membuat seseorang merasa dirinya lemah di depan Tuhan dan manusia, karena aqidah Jabar pada hakekatnya hanya bisa hidup atas penghapusan kepribadian dan wujud diri sendiri. Meskipun seharusnya penghapusan ini hanya terjadi dalam hubungan denga Tuhan saja, tetapi karena kelemahan pribadinya ia menganggap bahwa penghapusan tersebut juga berlaku dalam hubungannya dengan sesama makhluk. Salah satu ciri perbuatannya ialah selalu bersandar kepada orang lain, meskipun orang lain ini sebenarnya lebih lemah daripadanya. Bagaimanapun juga, paham Jabar sesuai dengan taqlid, yang keduaduanya menjadi tanda kelemahan dalam hidup. ${ }^{18}$

Muhammad Abduh tidak puas kalau kepercayaan seorang mu'min adalah kepercayaan Jabar, sebab kepercayaan ini sudah barang tentu akan mengakibatkan kelemahan manusia dan menyebabkan ia kehilangan daya kreasi dan posisi dalam hidupnya. Karena itu Muhammad Abduh menentang paham Jabar dan menyerukan paham Ikhtiar, agar seseorang muslim menjadi orang yang kreatif.

Dalam persoalan Jabar dan Ikhtiar ini, ia tidak bertindak sebagai seorang filosof, yang hanya mendasarkan pikirannya kepada tinjauan tertentu yang telah menguasai dirinya dan yang ingin menafsirkan kehidupan dan wujud ini atas dasar tinjauan tersebut melainkan ia bertindak selaku orang beragama dan penghubung antara dasar dan tujuan juga bercorak agama.

Dalam soal ikhtiar, ia menunjuk kepada ayat-ayat yang berisi penyandaran dan amal kepada manusia dan ayat-ayat lain yang mempertalikan balasan di akhirat dengan perbuatan dunia, seperti: "Sesunggubnya tidak ada pada manusia kecuali apa yang dikerjakannya dan pekerjaannya itu akan terlihat (an-Najm 39-40).

Argumentasi pikiran juga dikemukakannya, seperti yang biasa kita dengar dari aliran Mu'tazilah dalam membenarkan taklif, yaitu bahwa suatu taklif tidak mungkin akan mendatangkan balasan menurut

${ }^{17}$ Muhammad Rasyid Ridha, Tarikh al-Ustadz, hlm. 514.

${ }^{18}$ Ibid. 
pertimbangan akal, kecuali apabila manusia bisa bertanggungjawab. ${ }^{19}$

\section{b. Pertalian Akal dengan Wahyu}

Dalam menjelaskan pertalian akal dengan wahyu atau dengan perkataan lain, antara golongan rasionalis dengan golongan textualis dalam Islam, pendapat Muhammad Abduh sama dengan pendapat Ibn Rusyd yang hidup pada abad keenam Hijriah dan dengan pendapat Ibn Taimiyah yang hidup pada abad kedelapan Hijriah, yaitu bahwa wahyu mesti sesuai dengan akal. Ia mengatakan sebagai berikut:

“Qur'an memerintahkan kita untuk berfikir dan mengunakan akal pikiran tentang gejala-gejala alam yang ada didepan kita dan rahasiarahasia alam yang mungkin ditembus, untuk memperoleh keyakinan tentang apa yang ditunjukkan Tuhan kepada kita. Qur'an melarang kita bertaqlid, sewaktu menceritakan tentang umat-umat yang terdahulu yang dicela karena mereka merasa cukup mengikuti nenekmoyangnya. Taqlid adalah suatu kesesatan yang dapat dimengerti kalau terdapat pada hewan, akan tetapi tidak pantas sama sekali untuk manusia." 20

Katanya pula,

"Kami yakin, bahwa agama Islam adalah agama taubid dalam segisegi kepercayaan, bukan agama perpecahan dalam soal-soal pokok (prinsip). Akal pikiran menjadi kawan Islam yang terkuat, dan dalil naqal menjadi tiangnya yang utama. Selain itu hanyalah kemauan syetan atau keinginan orang-orang yang mau berkuasa." 21

Jadi wahyu dalam risalah Tuhan menjadi salah satu tanda kekuasaan Tuhan, dan akal juga menjadi salah satu tanda kekuasaan-Nya dalam wujud ini. Kedua tanda kekuasaan Tuhan mesti sesuai satu sama lain, dan tidak akan berlawanan, karena:

1. Kedua-duanya menjadi tanda kekuasaan Zat yang mutlak sempurna. Akal mahusia memustahilkan ada perlawanan antara tanda-tanda tersebut, karena perlawanan itu berarti suatu kelemahan.

\section{${ }^{19}$ Ibid., hlm. 513.}

${ }^{20}$ Abdullah Mahmud Syahatah, Manhaj al-Imam Mubammad Abdub fi Tafsir al-Qur'an al-Karim (Mesir: Mathba'ah Jami'ah al-Qahirah, 1984), hlm. 33.

${ }^{21}$ Ibid., hlm. 33-34. 
2. Wahyu sebagai petunjuk dan akal manusia juga menjadi sumber petunjuk. Kedua-duanya bertujuan menentukan jalan yang lurus untuk kehidupan manusia, dan menentukan tujuan terakhir dari kehidupan ini. Dua hal yang demikian keadaannya mesti tidak berbeda pada garis besarnya dalam menentukan jalan dan tujuan hidup manusia. ${ }^{22}$

Kalau kelihatannya ada perlawanan dalam penerapan Risalah wahyu dengan pemakaian akal, maka perlawanan itu disebabkan karena pengubahan Risalah wahyu atau karena salah memakai akal. Baik yang mengubah Risalah wahyu, maupun yang salah memakai akal, adalah manusia juga, bukan malaikat yang membawa wahyu, bukan pula Rasul yang menyapaikan Risalat itu.

Manusia sendiri yang memahami Qur'an dengan suatu pengertian yang jauh dari kebenaran, atau yang tidak sesuai dengan tujuannya yang pokok. Manusia itu sendiri pula yang membelokkan akalnya kepada sesuatu kepercayaan atau arah tertentu, sehingga tidak lagi menjadi akal yang murni, seperti yang dijadikan oleh Tuhan semula. Dengan demikian, maka manusia itulah yang menjadi sebab mengapa kitab Tuhan tidak sesuai dengan akal, dan akal pun tidak sesuai lagi dengan al-Kitab, bukan tabiat Qur'an, bukan pula tabiat akal sendiri yang menjadi sebabnya. ${ }^{23}$

Sebelum Muhammad Abduh, Ibn Rusyd, dengan nada yang sama, menulis bukunya yang berjudul "Fashl al-Maqâl fî mâ baina al-Hikmah wa al-Syariati min al-Ittishâl". ${ }^{24}$ Selain itu, Ibn Taimiyah juga menulis buku senada yang berjudul "Muwâfaqah al-Shabîh al-Manqûl li Sharîh al-Ma'qûl". (persesuaian dalil naqal yang sahih dengan dalil akal yang jelas (benar). ${ }^{25}$

Meskipun demikian, terdapat juga perbedaan di antara mereka. Ibn Rusyd meskipun bermaksud menghapuskan perbedaan antara alam pikiran Yunani dengan Islam, namun usaha yang dilakukan itu berlandaskan suatu prinsip tidak adanya perlawanan antara tabiat agama sebagai agama, dengan tabiat akal sebagai akal.

\footnotetext{
${ }^{22}$ A. Hanafi, Pengantar Theology Islam, hlm. 159-171.

${ }^{23}$ Muhammad Rasyid Ridha, Tarikh al-Ustadz, hlm. 514.

${ }^{24}$ A. Hanafi, Pengantar Theology Islam, hlm. 170-171.

${ }^{25}$ Ibid., hlm. 171.
} 
Ibn Taimiyah, meskipun dengan terang-terangan meminjam pikiranpikiran Yunani, namun ia membuktikan bahwa tabiat agama, kalau dinukil dengan jalan yang benar, tidak akan bertentangan dengan tabiat akal, kalau sekiranya akal ini terlepas dari prasangka dan tujuan-tujuan tertentu dalam kesimpulan-kesimpulan yang diambilnya. ${ }^{26}$

Akan tetapi tujuan Muhammad Abduh agak berbeda dalam menguraikan pertemuan wahyu dengan akal. Ia hendak menyatakan bahwa fitrah kejadian manusia yang berhubungan denga akal, tidak bertentangan dengan tanda lain dari kekuasaan Tuhan dan bekas-bekasnya pada alam semesta ini, terutama dengan Risalat-wahyu, seperti yang termuat dalam qur'an dan dalam bentuknya yang asli. ${ }^{27}$

\section{Sosial}

Mengenai permasalahan sosial, Muhammad Abduh membicarakan dua hal, yaitu sikap sosial dan kelemahan masyarakat Islam.

\section{a. Sikap Sosial}

Menurut Muhammad Abduh, sikap sosial dalam suatu ummat harus diperkuat. Sebaliknya, jiwa individualisme dan separatisme harus dikikis habis. Jalannya hanyalah pendidikan yang didasarkan atas dasar-dasar ajaran Islam, sebagai pendidikan yang benar. ${ }^{28}$

Kemiskinan suatu negeri disebabkan karena tidak ada jiwa pendirian agama dan mental yang menyebabkan seseorang tidak lagi berkeyakinan bahwa kepentingan negaranya atau bahaya yang menimpa negaranya lebih berbahaya dari pada yang menimpa dirinya. ${ }^{29}$

Muhammad Abduh menjelaskan bahwa harus terdapat pertalian antara ajaran-ajaran Islam dengan pengetahuan yang rasional serta pendidikan jiwa yang sebenarnya. ${ }^{30}$

${ }^{26}$ Ibid.

${ }^{27}$ Abdul Mu'in Hamadah, al Ustad al Imam Mubammad Abdub (Mesir: alMaktabah al-Tijariyah al-Kubro, tt.), hlm. 161.

${ }^{28}$ Utsman Amin, al-Imam Muhammad Abduh: Raidl al-Fikr al-Mishr (Mesir: Maktabah al-Mishriyah, 1965), hlm. 187.

${ }^{29}$ Asy-Syatibi, Al-Muwafaqat fi Usul asy-Syariah, jilid III (Beirut: Dar al-Ma'arif, tt.), hlm. 15 .

${ }^{30}$ A. Hanafi, Pengantar Theology Islam, hlm. 164-165. 
Menurut Muhammad Abduh, kelemahan umat dan masyarakat Islam hanyalah kemiskinan (kelemahan) jiwa dan bimbingan yang salah terhadap akal pikiran bukan karena tanah Mesir atau langitnya bukan pula karena tabiat alam (geografi) negeri-negeri Islam yang lain. Penyebab kemiskinan jiwa dan tuntunan yang salah akal pikiran ialah merajalelanya rasa ke-aku-an dan rusaknya arti "sikap sosial" pada jiwa seseorang. Hal ini disebabkan karena kebodohan mutlak atau karena salah memahami arti Islam dan kehidupan ini. ${ }^{31}$

Perbaikan keadaan tersebut bertujuan untuk mengembalikan sikap sosial, jiwa kenasionalan, dan jiwa keislaman serta kemanusiaan pada umumnya. Solusinya adalah ajaran-ajaran agama pada pendidikan dasar. Namun demikian, Muhammad Abduh tidak menginginkan agar pelajaranpelajaran di sekolah dasar hanya terdiri dari mata pelajaran agama saja, tetapi tetapi juga terdapat mata pelajaran umum dan tekhnik agar mampu bersaing dengan orang Barat dalam kemampuan menguasai hidup. ${ }^{32}$

Menurut Muhammad Abduh, orang kaya harus memberikan bantuan kepada orang miskin dalam hal pendidikan atau kebutuhan sosialnya. Karena orang miskinlah yang pertama kali terancam oleh orang asing, baik harta maupun jiwanya.

Muhammad Abduh memandang bahwa pengaruh yang positif dari pendidikan agama ke arah pembentukan sikap sosial tidak akan tercapai, kecuali sistem pendidikan dirubah dan kebudayaan (pengetahuan) Islam dijauhkan dari faktor-faktor penyelewengan yang menimpa. ${ }^{33}$

Kebanyakan orang hanya mengenal nama agama, sedang isinya tidak dikenalnya. Kalaupun mereka mempunyai kepercayaan (aqidah), maka aqidah Jabariah dan Murji'ahlah yang mereka pegangi. ${ }^{34}$

Perhatian orang-orang yang mengerti sedikit tentang agama hanya ditujukan pada persoalan a-thahârah dan al-najs, kewajiban shalat dan puasa saja. Mereka mengira bahwa lapangan agama hanya terbatas pada hal-hal itu saja. ${ }^{35}$

${ }^{31}$ Muhammad al-Bahi, al-Fikr al-Islâmî al-Hadîts wa Shiltub bi al-Isti'mâr alGharbî (Mesir: Mathba'ah Mukhaimar, 1957), hlm. 107.

${ }^{32}$ Ibid., hlm. 107.

${ }^{33}$ Ibid., hlm. 108-109.

${ }^{34}$ Muhammad Rasyid Ridha, Tarikh al-Ustadz, hlm. 513-514.

${ }^{35}$ A. Hanafi, Pengantar Theology Islam, hlm. 165-166. 
Ada sekelompok lain yang lebih maju, karena mereka telah memasuki persoalan mu'âmalah, tetapi tujuannya hanya untuk sekedar pencarian hidup. Kebanyakan dari mereka terdiri dari orang-orang yang hendak menduduki kursi fatwa, Pengadilan, atau mengajar. ${ }^{36}$ Agama bagi mereka tidak lain hanya alat untuk mencari penghidupan.

\section{b. Kelemahan Masyarakat Muslim}

Dalam hal ini, sebenarnya Muhammad Abduh lebih membicarakan kelemahan masyarakat Mesir, meski sebenarnya juga menjadi kelemahan masyarakat muslim yang lain. Kelemahan-kelemahan itu adalah:

1. Kesalahan dalam memahami arti hidup dikarenakan salah pendidikan dan tidak ada perhatian terhadap akhlak.

2. Pernikahan menurut Muhammad Abduh dipandang sebagai suatu keharusan. Menikah merupakan tabi'at manusia sebagai makhluk berpikir yang memiliki kecondongan naluri terhadap pasangan yang disukainya. Oleh karena itulah, poligami dianggapnya sebagai bencana masyarakat, karena baik orang kaya maupun miskinmenganggapnya sebagai alat untuk memuaskan hawa nafsu dengan melupakan tujuan poligami yang sebenarnya. ${ }^{37}$

3. Bid'ah (dalam hal ibadah) juga merupakan penyebab lemahnya masyarakat, karena menunjukkan penyelewengan terhadap aqidah.

4. Muhammad Abduh mencela keras praktek suap-menyuap yang dipandangnya sebagai tanda kemerosotan akhlaq dan kehilangan rasa kewajiban.

5. Acuh tak acuh terhadap kepentingan umum. Hal ini disebabkan karena putusnya hubungan jiwa satu sama lain. ${ }^{38}$

${ }^{36}$ Kursi fatwa dan Pengadilan pada saat itu adalah kedudukan yang strategis, sehingga paling banyak diminati orang. Dalam konteks saat ini, mungkin bukan kursi fatwa lagi, melainkan meluas pada aspek jabatan yang lain, seperti petugas pajak, pejabat keuangan, dan sejenisnya. Lihat A. Hanafi, Pengantar Theology Islam, hlm.164; Muhammad al-Bahi, al-Fikr al-Islâmî al-Hadîts, hlm. 110.

${ }^{37} \mathrm{Hal}$ ini sebenarnya juga dikarenakan pengalaman masa kecilnya yang kurang begitu menyenangkan. Muhammad Abduh harus tinggal dalam satu rumah bersama saudara-saudaranya yang banyak dari beberapa ibu (istri-istri ayah Muhammad Abduh). Lihat Imam Munawir, Mengenal Pribadi 30 Pendekar dan Pemikir Islam dari Masa ke Masa, hlm. 495; A. Hanafi, Pengantar Theology Islam, hlm. 156.

${ }^{38}$ A. Hanafi, Pengantar Theology Islam, hlm.165-166. 


\section{Politik Hukum}

Gagasan pemikiran politik Muhammad abduh dapat terlihat dalam:

1. Arti Tanah Air

Muhammad Abduh mengariskan kedudukan tanah air dengan adanya hubungan yang erat dari seseorang warga negara dengan tanah airnya. Ada tiga hal yang mengharuskan seseorang cinta, ghairah dan mempertahankan tanah airnya, yaitu:

a. Sebagai tempat kediaman yang memberikan makanan, perlindungan, dan tempat tinggal keluarga dan sanak saudara;

b. Sebagai tempat memperoleh hak-hak dan kewajiban-kewajiban yang kedua-duanya menjadi poros (dasar) kehiduan;

c. Tempat mempertalikan diri dimana seseorang akan merasa bangga atau terhina karenanya. ${ }^{39}$

2. Demokrasi dan Pemerintahan

Prinsip demokrasi harus dipegangi bersama baik oleh penguasa maupun rakyat biasa. Sejarah Islam menjadi bukti, betapa kuat demokrasi yang dianut oleh kaum muslimin, pada masa-masa pertama Islam, sebagaimana yang diterapkan oleh khalifah Umar r.a. dan kaumnya, ketika ia berkata dihadapan mereka, "wahai kaum muslimin, barang siapa melihat suatu penyelewengan pada diriku, hendaklah ia meluruskan." Maka berdirilah seorang dari mereka seraya berkata, "Demi Tuhan, kalau kami dapati pada diri tuan suatu penyelewengan, maka akan kami luruskan dengan pedang kami”. Berkatalah Umar r.a., "Alhamdulillah, Tuhan telah menjadikan diantara kaum muslimin orang yang sanggup meluruskan penyelewengan Umar dengan pedangnya." 40

Menurut Muhammad Abduh, kalau perinsip demokrasi menjadi suatu kewajiban bagi rakyat dan penguasa bersama-sama, maka kewajiban pemerintah terhadap rakyat ialah memberikan kesempatan selua-luasnya untuk bekerja dengan bebas dan dengan cara yang benar, agar dapat mewujudkan kebaikan dirinya dan masyarakat.

3. Hubungan Undang-undang dengan sosio kultural Orang akan keliru kalau mengira bahwa undang-undang yang adil

\footnotetext{
${ }^{39}$ Muhammad al-Bahi, al-Fikr al-Islâmî al-Hadîts, hlm. 99.

${ }^{40}$ A. Hanafi, Pengantar Theology Islam, hlm.160-161.
} 
dan yang sesuai dengan prinsip kemerdekaan ialah undang-undang yang cocok dengan dasar-dasar kebudayaan dan politik yang berlaku di negeri lain, karena tiap-tiap negeri berbeda satu sama lain, disebabkan karena perbedaan geografisnya dan keadaan perdagangan serta pertaniannya. Demikian kedudukannya juga berbeda-beda, baik dalam adat kebisaan, akhlak, kepercayaan dan sebagainya. Banyak undang-undang yang sesuai untuk satu bangsa, tetapi merugikan bagi yang lain. ${ }^{41}$

Karena itu orang yang membuat undang-undang hendaklah memperhartikan perbedaan-perbedaan di kalangan rakyat, baik tingkatan kecerdasannya maupun keadaan sosialnya, tabiat tanah negerinya, kepercayaan dan kebisaannya agar pembuat undangundang tersebut bisa menggariskan kepentingan mereka dan mempertalikan pekerjaan mereka dengan batas-batas yang bisa membawa faidah dan menutup pintu keburukan. Karena itu pula ia tidak boleh meniru Negara lain dalam pembuatan undang-undang. ${ }^{42}$

Menurut Muhammad Abduh, fungsi undang-undang hanya untuk memelihara keadaan yang sudah ada, bukan untuk mengadakan perubahan secara serentak. Perubahan akhlak dan adat umat hanya bisa dicapai dengan pendidikan, bukan dengan undang-undang. ${ }^{43}$

Undang-undang yang menentukan suatu hukuman atas suatu kejahatan atau pelanggaran tidak akan bisa mendidik untuk memperbaikinya, karena semua undang-undang di dunia ini dibuat untuk orang-orang yang menyeleweng dan salah, sedang undangundang yang membawa perbaikan ialah undang-undang pendidikan agama pada setiap umat. $^{44}$

${ }^{41}$ Abdul Halim Mahmud, Manahij al-Mufassirin (Mesir: Dar al-Kutub, tt.), hlm. 308.

${ }^{42}$ Yang dimaksud dengan "tidak boleh meniru” disini adalah meniru sama persis peraturannya (materiil), padahal situasi, kondisi, dan kebudayaannya berbeda. Jika meniru cara perumusan undang-undangnya (formil) saja, maka hal ini diperbolehkan. Lihat A. Hanafi, Pengantar Theology Islam, hlm. 160-161.

${ }^{43}$ Muhammad al-Bahi, al-Fikr al-Islâmî al-Hadîts, hlm. 99; Utsman Amin, alImam Muhammad Abduh, hlm. 187; Abdul Halim Mahmud, Manabij al-Mufassirin, hlm. 307-308.

${ }^{44}$ Muhammad al-Bahi, al-Fikr al-Islâmî al-Hadîts, hlm. 102-104. 


\section{Pendidikan}

Berkaitan dengan pendidikan ini, Muhammad Abduh membicarakan empat persoalan:

1. Fanatik Mazhab

Muhammad Abduh mendapati masyarakat Islam sudah terpecah-belah menjadi golongan dan aliran-aliran, sehingga tidak lagi merupakan satu kesatuan umat yang mempunyai unsur-unsur kejayaannya. Hal ini disebabkan karena kuatnya pemujaan mutlak terhadap mazhabmazhab yang telah ada. Sebenarnya beranekanya mazhab dan aliran, baik dalam lapangan hukum atau aqidah, tidak membahayakan umat. Tetapi yang membahayakan ialah kuatnya kekuasaan mazhab atau aliran itu pada diri pemeluk-pemeluknya, sehingga tidak berani mengkritik atau mengadakan evaluasi terhadapnya. Dengan demikian, maka umat Islam menjadi bermacam-macam masyarakat atau golongan yang terpisah satu sama lain oleh dinding kefanatikan mazhab atau aliran yang kuat, sehingga tidak bisa bersama-sama mengikuti tuntunan Islam yang satu dan berjalan ke arah tujuan yang sama.

Antara aliran-aliran Teologi Islam sendiri terdapat jurang pemisah. Lebih dalam lagi ialah jurang yang terdapat antara ulama-ulama Teologi Islam di satu pihak dengan ahli-ahli pikir dan filosof-filosof di lain pihak. Demikian pula halnya dengan aliran-aliran dalam hukum Islam (fiqh), yaitu aliran-aliran yang memberikan tuntunan dalam bidang mu'amalat manusia satu sama lain dan bidang ibadat manusia terhadap Tuhan. Aliran-aliran tersebut saling bermusuhan dan saling mencela. ${ }^{45}$

Karena itu, Muhammad Abduh mengadakan evaluasi terhadap aliran-aliran tersebut, dengan tidak memberikan penilaian yang mutlak atas sesuatu aliran tertentu. Aliran-aliran tersebut semuanya dipandangnya sebagai pengulas (syârib) dasar-dasar Islam dan ajaranajarannya, yang bisa salah atau benar, sesuai dengan sifat pengulas tersebut. Oleh karena itu, uatu mazhab atau aliran, terutama pengikut-pengikutnya, tidak berhak sama sekali untuk mengatakan bahwa hanya dirinya semata yang benar atau yang mencerminkan

\footnotetext{
${ }^{45}$ Muhammad Rasyid Ridha, Tarikh al-Ustadz, hlm. 513-514.
} 
Islam yang sebenarnya. Evaluasi dari Muhammad Abduh ini dapat kita lihat dari sikapnya terhadap ilmu Teologi Islam (ilmu tauhid) dan dari pendapatnya tentang aliran-aliran Teologi Islam yang selamat. ${ }^{46}$

Ulama-ulama Islam pada masanya, terutama ulama-ulama alAzhar, menganggap bahwa ilmu Tauhid, dengan segala perdebatan yang terdapat dalam kitab-kitab ilmu tersebut antara aliran-aliran ilmu kalam waktu membentangkan dalil-dalilnya masing-masing, merupakan jalan yang baik untuk menanamkan aqidah yang benar terhadap Tuhan di antara kaum muslimin. Karena itu kedudukan ilmu Tauhid, di antara ilmu-ilmu keislaman yang menjadi bahan tuntunan Islam datang (tingkatannya) sesudah Al- Qur'an dan ilmu-ilmu alAl-Qur'an.

Berbeda dengan pandangan ulama-ulama masanya tersebut, Muhammad Abduh memberikan penilaian lain terhadap ilmu Tauhid dan penilaiannya ini sesuai dengan apa yang pernah dikemukakan oleh Imam al-Ghazali dan Imam al-Juwaini. Yaitu bahwa ilmu Tauhid hanya bisa dipakai untuk melatih akal-pikiran, tetapi tidak bisa menjadi alat untuk menanamkan aqidah Islam ataupun mengokohkannya sama sekali. Jalan yang terbaik untuk itu adalah metode al-Qur'an sendiri dalam menguraikan dakwah Islamiah dan mengajak orang banyak untuk memenuhi suruhan itu, yaitu metode "iqnâ'i" (pemuasan hati), suatu metode yang memperhatikan fitrah manusia yang universal. Oleh karena itu metode tersebut sesuai untuk agama sebab agama itu suatu tuntunan untuk semua orang, bukan hanya untuk segolongan tertentu dalam masyarakat manusia. ${ }^{47}$

Akan tetapi ilmu Kalam (Teologi Islam) dalam semua aliranalirannya, seperti yang dilukiskan oleh kitab-kitab karangan ulamaulama mutaakhirîn, sudah jauh sekali dari metode tersebut, karena ilmu tersebut memakai logika Aristoteles. Dengan demikian maka ilmu Kalam menjadi alat perdebatan bagi orang-orang tertentu yang telah berkenalan dengan alam pikiran Yunani dan telah merasakan lezatnya logika formal dalam sesuatu pembuktian. ${ }^{48}$

${ }^{46}$ Muhammad al-Bahi, al-Fikr al-Islâmî al-Hadîts, hlm. 97-99.

${ }^{47}$ A. Hanafi, Pengantar Theology Islam, hlm. 48 dan 172-173.

${ }^{48}$ Asy-Syatibi, Al-Muwafaqat fi Usul asy-Syariah, jilid III (Beirut: Dar al-Ma'arif, tt.), hlm. 15 . 
Pendapat Muhammad Abduh tentang aliran-aliran Teologi Islam dikemukakan dalam ulasannya terhadap kitab Syarb Risâlah al-Adûdiah, karangan Jalaluddin ad-Dawwani. Al Iji, pengarang matan risalah tersebut, waktu menafsirkan hadis Nabi tentang perpecahan umat menjadi 73 golongan, di mana golongan yang selamat hanya satu, maka dikatakannya bahwa yang dimaksud oleh hadis tersebut ialah aliran Asy'ariah. Atas tafsiran ini Muhammad Abduh mengatakan bahwa hadis Nabi tersebut berisi tiga hal, yaitu:

a. Ada perpecahan di kalangan umat, sehingga menjadi bermacammacam golongan.

b. Di antara golongan-golongan itu yang selamat hanya satu,

c. Yang selamat, seperti yang dijelaskan oleh Nabi sendiri, ialah yang menetapi apa yang dijalankan oleh Nabi dan sahabat-sababatnya (mengikuti jejak Nabi dan sahabat- sahabatnya). ${ }^{49}$

Perpecahan umat Islam menjadi golongan-golongan, benar-benar telah terjadi baik telah mencapai jumlah 73 atau tidak. Ketentuan bahwa yang selamat hanya satu juga benar, karena kebenaran itu hanya satu, yaitu yang dijalankan oleh Nabi dan sahabat-sahabatnya. Akan tetapi menentukan siapa golongan yang selamat itu, yaitu yang mengikuti jejak Nabi dan sahabat-sahabatnya, belum lagi jelas, sebab masing-masing golongan yang menyatakan mengikuti Nabi kita, akan mengatakan bahwa dirinya mengikuti jejak Nabi dan sahabatsahabatnya, serta menganggap dirinya golongan yang selamat. ${ }^{50}$

Dengan pendapat tersebut, Muhammad Abduh telah menggoyahkan pemujaan dan kefanatikan terhadap mazhab, dan keagungan mazhab atau aliran yang sebenarnya hanya dibuat-buat oleh pengikut-pengikutnya, serta kekuasaan mutlak mazhab atau aliran tersebut atas jiwa mereka. Dengan tindakannya itu, ia bermaksud agar umat Islam kembali kepada sumber Islam yang pertama, yaitu Al-Al-Qur'an, kemudian hadis yang sahih, sebagaimana yang terjadi pada masa-masa pertama Islam. Dengan jalan tersebut ia yakin bahwa kekuasaan dan pengokohan kembali masyarakat Islam akan terwujud. ${ }^{11}$

${ }^{49}$ Muhammad al-Bahi, al-Fikr al-Islâmî al-Hadîts, hlm. 131-133.

${ }^{50}$ Ibid.

${ }^{51}$ Ibid., hlm. 135-136. 
2. Ijtihad dan Taqlid

Untuk menjaga keselamatan dan kesuksesan berpikir, seseorang muslim harus kembali kepada Al-Qur'an, baik dalam dasar-dasar aqidah maupun amalan. Perkataan seseorang tidak bisa dijadikan pegangan, apabila berlawanan dengan Al-Qur'an secara jelas. Kalau tidak demikian, maka perbedaan pendapatlah yang akan timbul dan mazhab-mazhab itu akan menghalang-halangi kitab Tuhan. Dengan demikian, maka hilanglah pengertian Kitab tersebut dan lenyap pula hikmah yang diturunkannya, karena mereka mempertautkan diri dengan perkataan seseorang yang tidak ma'shûm. Seolah-olah mereka tidak pernah kedatangan Risalah dan apa yang menjadi pegangan hidupnya hanya perkataan pemimpin-pemimpin mereka. ${ }^{52}$

Dua hal yang mendorong Muhammad Abduh untuk menyerukan Ijtihad, yaitu tabiat hidup dan tuntunan masyarakat manusia. Kehidupan manusia ini berjalan terus dan selalu berkembang dan di dalamnya terdapat kejadian dan peristiwa yang tidak dikenal oleh masa sebelumnya. Ijtihad adalah jalan ideal dan praktis yang bisa dijalankan untuk mempertalikan peristiwa-peristiwa hidup yang selalu timbul itu dengan ajaran-ajaran Islam. Kalau ajaran Islam tersebut harus berhenti pada penyelidikan ulama terdahulu, maka kehidupan manusia dalam masyarakat Islam akan menjadi jauh dari tuntunan Islam, suatu hal yang akan menyulitkan mereka, baik dalam kehidupan beragama maupun dalam kehidupan dunia. Akibatnya, nilai Islam akan menjadi berkurang dalam jiwa mereka, karena kehidupan mereka dengan segala persoalannya lebih berat tekanannya, atau mereka tidak akan sanggup mengikuti arus hidup dan selanjutnya mereka akan terasing dari kehidupan itu sendiri, serta berlawanan dengan hidup dan hukum hidup juga. ${ }^{53}$

Meskipun Ijtihad merupakan jalan yang baik dan merupakan suatu keharusan untuk memberikan corak keislaman terhadap kejadian masyarakat dalam lingkungan Islam, namun ijtihad itu hanya boleh dijalankan oleh orang-prang yang mempunyai sifat-sifat

52 A. Hanafi, Pengantar Theology Islam, hlm. 175; Muhammad Rasyid Ridha, Tarikh al-Ustadz, hlm. 514-515.

${ }^{53}$ Abdul Mu'in Hamadah, al Ustad al Imam Mubammad Abdub (Mesir: alMaktabah al-Tijariyah al-Kubro, tt.), hlm. 161. 
keilmuan, seperti yang dimiliki oleh seorang mujtahid pada masa tiga abad pertama Hijrah. Karena itu Muhammad Abduh mensyaratkan kebolehan ljtihad dengan syarat tersebut, baik untuk masanya atau masa sesudahnya, dan ia juga berhati-hati sekali dalam soal syarat ini, tidak kurang ketelitiannya dengan orang-orang yang terdahulu.

Muhammad Abduh sangat mencela taqlid, karena dengan taqlid itu akal manusia didudukkan dalam suatu tempat tertentu yang tidak boleh dilampauinya. Hal ini bertentangan dengan fungsi akal, dengan tabiat hidup dan dengan sifat prinsip-prinsip Islam itu sendiri. ${ }^{54}$

Muhammad Abduh bukan saja mencela taqlid sebagai suatu prinsip, tetapi juga karena taqlid pada masanya telah mencapai bentuk sedemikian rupa, yaitu ketundukan bulat-bulat terhadap kekuasaan mazhab yang telah menggariskan arah tertentu yang menyimpang dari jalan yang lurus, sebagai akibat warisan masa kemunduran pikiran, politik, dan ekonomi dalam masyarakat Islam, di samping ketundukan bulat-bulat terhadap kitab-kitab yang berisi persoalanpersoalan yang tidak terdapat dalam hidup yang nyata, di mana bahasanya sering-sering janggal, dan bertendensi pula memperkuat pertentangan mazhab.

3. Kekuasaan Kitab-kitab Tertentu

Menurut Muhammad Abduh pengaruh kitab-kitab yang dikarang pada masa mutakhir, sama dengan pengaruh kefanatikan mazhab yang telah dibicarakan di atas, yaitu pengaruh negatif dalam memberikan bimbingan serta menghambat jalan alam pikiran Islam, sehingga tidak dapat menghadapi peristiwa hidup dan mengimbangi perkembangannya. ${ }^{55}$

Muhammad Abduh mencela perumitan pembahasan dalam soalsoal ibadah, sedang dalam urusan mu'amalat hanya mendangkal saja. Dalam hal ini ia berkata sebagai berikut:

"Masyarakat selalu mengalami hal-hal/ peristiwa yang tidak tercantum dalam kitab-kitab tersebut (kitab-kitab fiqh). Apakah kita akan menghentikan jalan dunia, demi untuk mempertahankan kedudukan kitab-kitab tersebut? Tentu tidak mungkin. Oleh karena itu orang-orang bisa dan para penguasa

\footnotetext{
${ }^{54}$ Muhammad al-Bahi, al-Fikr al-Islâmî al-Hadîts, hlm. 137-138.

${ }^{55}$ Asy-Syatibi, Al-Muwafaqat fi Usul asy-Syariah, 15-17.
} 
terpaksa meninggalkan hukum-hukum Syara' untuk mencari yang lain. Para fuqaha'lah yang bertanggung jawab tentang keadaan yang demikian dan tentang larinya orang banyak dari Syara'. Seharusnya para fuqaha mengetahui keadaan masa dan zaman untuk kemudian menerapkan hukum-hukum (agama) atasnya, seperti hukum "Darurat" (keadaan terpaksa), dengan cara yang bisa diikuti oleh orang banyak. Mereka tidak cukup hanya dengan memegangi tulisan dan bunyi kitab-kitab tersebut dan menganggapnya benar seluruhnya, dengan meninggalkan yang lainnya. Muhammad Abduh selanjutnya berkata, "Mereka membaca kitab-kitab Usul (usul fiqh). Tetapi seorang pun tidak terlintas dalam hatinya untuk mengembalikan soal-soal furu' dalam kitab-kitab fiqh kepada landasannya (asalnya) ataupun mencarikan dalilnya. Bahkan mereka dengan tidak malu-malu lagi berkata, "Kami ini bertaqlid, tidak perlu mencari dalam Al-Qur'an dan Sunnah". Mereka merasa terikat erat langsung dengan kitab-kitab karangan ulama-ulama sebelumnya, meskipun saling berlawanan dan bertentangan isinya, yang telah mencerai-beraikan kesatuan umat Islam. Para fuqaha sudah merasa cukup untuk mengatakan: "Toh mereka semua dari Rasul juga menerimanya (menerima ilmu)." 56

4. Menghiduphan kembali Kitab-kitab Lama dan Membaca Gaya Baru dalam Penafsiran Al-Qur'an

Kalau Muhammad Abduh mencela kitab-kitab ulama mutaakhirin, maka logis sekali apabila ia tidak mengurangi nilai warisan (kitab) keislaman dan kearaban yang lain dan yang harus dijadikan dasar perbaikan dunia Islam dalam mengimbangi kehidupan yang nyata.

Kelanjutannya ialah bahwa warisan lama harus dihidupkan, dan untuk ini ia benar-benar telah menanggulangi sendiri, di samping mendorong murid-muridnya dan para penguasa masanya untuk bertindak yang sama. Ia sendiri memberikan ulasan terhadap buku "al-Bashairun Nashiriah" dalam ilmu mantiq (logika) dan menerbitkan serta memberikan ulasan terhadap buku kesusasteraan "Nabjul Balaghab" dan kitab-kitab lainnya. ${ }^{57}$

${ }^{56}$ Muhammad al-Bahi, al-Fikr al-Islâmî al-Hadîts, hlm. 140-142.

${ }^{57}$ Muhtarom, "Pembaharuan Metodologi Tafsir: Muhammad Abduh," dalam Jurnal Teologia, Vol. 12. No. 3. Oktober 2001, hlm. 355-356. 
Dalam bidang karang-mengarang ia telah meletakkan dasar-dasar baru dan metode tersendiri dalam penafsiran Al-Qur'an. Dasar-dasar dan metode tersebut terlihat dalam bukunya "Risalatut Taubid" dan Tafsir-tafsirnya. Khusus mengenai Tafsirnya, dasar-dasar tersebut ialah:

a. Menundukkan peristiwa-peristiwa hidup yang terjadi pada masanya kepada nash-nash Al-Qur'an, baik dengan jalan perluasan arti ayat atau dengan jalan analogi.

b. Al-Qur'an seluruhnya merupakan satu kesatuan, di mana pemahaman terhadap sebagiannya tidak dipisahkan dari bagian yang lain dan kesemuanya harus dipercayai, tidak boleh hanya sebagiannya saja.

c. Keseluruhan isi suatu Surat Al-Qur'an dijadikan dasar pemahaman terhadap ayat-ayat yang termuat di dalamnya.

d. Menjauhkan segi-segi ilmu bahasa dari lapangan Tafsir Al-Qur'an dan menjauhkan tafsirannya dari sekedar latihan untuk memiliki bakat bahasa.

e. Tidak melupakan peristiwa-peristiwa sejarah, sepanjang dakwah Islam dalam menafsirkan ayat-ayat yang turun karenanya. ${ }^{58}$

\section{Pro-Kontra terhadap Muhammad Abduh}

Max Horten mengatakan sebagai berikut, "M. Abduh pada akhir abad yang lalu (abad 19) merupakan lampu lilin yang terang, bukan saja karena keadaan sekelilingnya sangat gelap, sedang ia sendiri kurang cahayanya, tetapi karena orang pada masanya tidak mau mengenalnya, bahkan menentangnya, jadi sinar yang sebenarnya tidak terlihat". ${ }^{59}$

Michel mengatakan sebagai berikut, "Syek M. Abduh terlalu optimistis, lebih daripada yang sebenarnya, di mana ia mengatakan bahwa ilmu pengetahuan dapat bersatu dengan agama di semua tempat, sedang ilmu pengetahuan kadang-kadang tidak tunduk kepada agama, seperti yang terjadi di Eropa. Boleh jadi dengan pendapatnya itu M. Abduh bermaksud mendorong ulama-ulama Islam untuk mempelajari kebudayaan baru dan berpendapat bahwa hal itu adalah satu-satunya jalan ke arah itu".

\footnotetext{
${ }^{58}$ Abdullah Mahmud Syahatah, Manhaj al-Imam, hlm. 33-35.

${ }^{59}$ Ibid., hlm. 183.
} 
J. Schacht dalam ulasannya terhadap pandangan M. Abduh mengatakan bahwa Islam masa pertama (Islam yang asli) dalam pandangan M. Abduh bukan Islam yang terkenal dalam sejarah, melainkan Islam idealist (idam-idaman). Islam dipandangnya melebihi agama Masehi karena Islam adalah agama Yang rasional dan berhubungan erat dengan kehidupan yang nyata. Jasanya (M. Abduh) bagi Islam, ialah usahanya yang bercorak mempertahankan aqidah. Darma-baktinya dalam gagasan pembaharuan agama ialah usahanya untuk membuat tempat bagi Islam dalam dunia baru. ${ }^{60}$

Dengan perkataan-perkataaanya itu para orientalis tersebut seolah-olah hendak menekankan bahwa persesuaian Islam dengan ilmu pengetahuan, ketinggian ajarannya dan kegunaannya untuk kehidupan, tidak seperti yang dilukiskan oleh M. Abduh, karena ia adalah orang yang optimistis-idealist, yang hendak membelanya dan oleh karena itu diberinya corak yang idealist pula, sebagaimana ia hendak memberikan tempat untuk Islam dan kehidupan modern, meskipun tempat yang sebenarnya tidak ada. Demikianlah nasib seseorang yang membela Islam dengan segala keikhlasan melalui tulisan-tulisannya.

Ahmad Amin dalam bukunya "Zu'amaul Ishlah", waktu memperbandingkan antara M. Abduh dari Mesir dengan Ahmad Chan dari India, mengatakan sebagai berikut, "Kedua-duanya berpendapat, bahwa kekuasaan di India dan di Mesir berada di tangan orang-orang Inggeris, sedang mereka mempunyai kekuatan material, berupa senjata dan amunisi di darat dan di laut, dan juga kekuatan ilmu pengetahuan dan politik, yang kesemuanya tidak bisa dilawan oleh orang-orang India maupun Mesir. Boleh jadi mereka dapat mengadakan perlawanan, sedang mereka masih bodoh dan merosot akhlaknya. Bagaimana hal itu bisa terjadi, sedang para penguasanya sudah rusak dan yang dicarinya hanya kepentingan mereka sendiri, meskipun merugikan bangsa? Maka putusan keduanya: Kalau begitu, lebih baik damai dan berunding dengan Inggeris serta mengambil apa yang dapat kita ambil dari mereka untuk kebaikan rakyat". Demikianlah kata Ahmad Amin.

Khusus mengenai M. Abduh, Ahmad Amin menunjuk kepada kerjasamanya dengan Lord Cromer. Tetapi kerja sama (perdamaian) ini sebenarnya dimaksudkan untuk mencari perlindungan dari tekanan

${ }^{60} \mathrm{Ibid} .$, hlm. 184. 
Khedive Abbas II yang tindakannya merugikan bangsa dan agamanya, sehingga dengan demikian M. Abduh bisa menyatakan pikiran-pikirannya dengan leluasa tentang perbaikan al-Azhar dan bisa meneruskan kegiatankegiatannya dalam lapangan juris-prudensi fiqh dan dalam kuliah-kuliah serta pembicaraan-pembicaraannya yang bersifat bimbingan dan ilmiah. Juga dimaksudkan untuk melindungi tanah wakaf kaum muslimin yang diambil oleh Khedive tersebut dan digabungkan dengan hak miliknya sendiri. Dalam pada itu sejarah masa lampau M. Abduh cukup menunjukkan perjuangannya yang gigih untuk menentang penjajahan.

Bagaimana pun juga penolakan dan cemoohan lawan-lawan M. Abduh, namun pikiran dan ajaran-ajarannya mendapat sambutan kalangan kaum muslimin yang terbuka pikirannya sampai sekarang. Rumah tempat ia dilahirkan dijadikan sebagai monumen bersejarah. Selain itu, ruang ceramah di al-Azhar dinamai dengan nama M. Abduh, dan sejak tahun 1931 beasiswa untuk mahasiswa al-Azhar juga menggunakan namanya. ${ }^{61}$

\section{Kesimpulan}

Muhammad Abduh dilahirkan pada tahun 1849 M (1265 H) di Mahallah Nasr, suatu perkampungan agraris termasuk Mesir Hilir di propinsi Gharbiyyah. Ayahnya bemama Abduh bin Hasan Chairullah seorang berdarah Turki, sedangkan ibunya Junainah (Yatimah) binti Utsman al-Kabir mempunyai silsilah keluarga besar keturunan Umar Ibn al Khatab. Pendidikan menulis dan membaca dijalani dalam lingkungan keluarga. Setelah usia 10 tahun sang ayah mengirimnya untuk belajar al-Qur'an di Masjid Ahmadi kota Thanta yang terkenal mempunyai spesialisasi dalam kajian Qur'an.

Pengaruh intelektual paling besar pada Muhammad Abduh terjadi setelah ia bertemu Sayyid Jamaluddin al-Afghani (1839-1897M) yang datang ke Mesir pada tahun 1871. Muhammad Abduh sangat antusias mengikuti kuliah dan ceramah-ceramah yang diberikannya.

Aktifitas politik Muhammad Abduh adalah dia pernah oposisi terhadap Kadefi Taufiq sehingga dia diasing ke luar Mesir pada tahun 1879. tahun 1880 ia kembali ke Mesir dan memimpin majalah al-Waqai'

${ }^{61}$ Ibid., hlm. 183-185. 
al-Mishriyah. Dia juga mendukung pemberontakan Urabi Pasha pada tahun 1882 yang membuatnya terusir ke Beirut. Pada tahun 1884 mendirikan majalah al-Urwah al-Wutsqâ.

Sedangkan aktifitas non-politik Abduh adalah Dosen al-Jamiah al-Azhar, Hakim Agung, Anggota dewan tertinggi al-Azhar, wartawan majalah al-Manar, dan menjadi Mufti Mesir sampai wafatnya (1905 M.).

Karyanya yang terkenal adalah Kitab al-Radd alâ al-Dabriyyîn yang merupakan terjemahan dari buku Jamaluddin al-Afghani yang berbahasa Persia, Syarh al-Balâghah, Syarh Maqâmât Badî' al-Zamân al-Hamazanî, Risâlab al-Taubîd, al Islâm wa al-Nashrâniyyah ma'a al-Ilm wa al-Madaniyyah, Ulasan buku al-Bashâir al-Nashîriyyah karya alQadhi Zainuddin, dan Tafsir al-Manar yang dilanjutkan oleh muridnya, Muhammad Rasyid Ridha. 


\section{DAFTAR PUSTAKA}

Ahmed, Jamal Muhammad, The Intellectual Origius of Egyptian Nasionalism, London: Oxford Universitas Press, 1960.

Ali, A. Mukti, Alam Pikiran Islam Modern di Timur Tengah, Jakarta: Djambatan, 1995.

Amin, Ahmad, Zu'ama' al Islah fi al-Ashr al-Hadits (Kairo: Maktabah al-Nahdhah al-Misriyah, 1979.

Amin, Ustman, Muhammad Abduh, ttp.: tp., tt.

---------, al-Imam Muhammad Abduh: Raidl al-Fikr al-Mishr, Mesir: Maktabah al-Mishriyah, 1965.

Bahi al-, Muhammad, al-Fikr al-Islâmî al-Hadîts wa Shiltub bi al-Isti'mâr

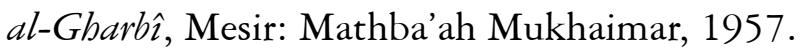

Belling dan Totten, Modernisasi dan Masalab Model Pembangunan, Jakarta: Yayasan Ilmu-ilmu Sosial, 1985.

Hamadah, Abdul Mu'in, al Ustad al Imam Mubammad Abduh, Mesir: alMaktabah al-Tijariyah al-Kubra, tt.

Hanafi, A., Pengantar Theology Islam, Jakarta: al-Husna Zikra, 1995.

aq, Mahmudul, Muhammad Abduh: A Study of A Modern Thinker of Egypt, Aligarkh: Muslim University, 1970.

Ma'arif, Syafi' i, Peta Intelektual Muslim Indonesia, Bandung: Mizan, 1994.

Mahmud, Abd. Halim, Manâhij al-Muhassirîn, Mesir: Dar al-Kitab alMishri, tt.

Mahmud, Abdul Halim, Manahij al-Mufassirin, Mesir: Dar al-Kutub, tt.

Muhtarom, "Pembaharuan Metodologi Tafsir: Muhammad Abduh," dalam Jurnal Teologia, Vol. 12. No. 3. Oktober 2001.

Mulkhan, Abdul Munir, Paradigma Intelektual Muslim, Pengantar Filsafat Pendidikan dan Dakwah, Yogyakarta: SI Press, 1993..

Munawir, Imam, Mengenal Pribadi 30 Pendekar dan Pemikir Islam dari Masa ke Masa, Surabaya: Bina Ilmu, 1985. 
Nasution, Harun, Pembaharuan Dalam Islam Sejarah Pemikiran dan Gerakan, Jakarta: Bulan Bintang, 1975.

Ridla, Muhammad Rasyid, Tarikh al-Ustadz al-Imam al-Syaikh Mubammad 'Abduh, jilid III, Mesir: Dar al Manar, 1931.

Suharto, Toto, Filsafat Pendidikan Islam, cetakan ke-I, Yogyakarta: alRuzz, 2006.

Syahatah, Abdullah Mahmud, Manhaj al-Imam Muhammad Abdub fi Tafsir al-Qur'an al-Karim, Mesir: Mathba'ah Jami'ah al-Qahirah, 1984.

Syatibi Asy-, Al-Muwafaqat fi Usul asy-Syariah, jilid III, Beirut: Dar alMa'arif, tt. 